\title{
Diatoms diversity in Oubeïra Lake, northeastern Algeria
}

\author{
Chabaca Hasna ${ }^{*}$, Marniche Faiza ${ }^{2} \&$ Tadjine Aicha $^{3}$ \\ ${ }^{1}$ Department of Biology, Laboratory of Functional and Evolutionary Ecology, University El Tarf, Algeria \\ ${ }^{2}$ Faculty of Veterinary Sciences, National Veterinary School-Algiers, Algeria \\ ${ }^{3}$ Faculty of Veterinary Sciences, El Tarf University, Algeria \\ ${ }^{*}$ Corresponding author, email: Chabaca.h@hotmail.fr
}

\begin{abstract}
Mediterranean wetlands are currently subjected to habitat loss and degradation derived from pollution, climate change, eutrophication and the occurrence of exotic species as the most important threats, affecting numerous taxonomic groups. Different tools are being used to assess water quality conditions in these environments, including physicochemical measurements and biological indicators (fish, invertebrates, and diatoms). We aim to study the diversity and ecology of the diatom assemblage inhabiting the RAMSAR site Oubeïra Lake in northeastern Algeria, contributing to the catalogue of diatoms recorded for Algeria. The identification of the morphological characters allowed us to make an inventory of 18 genera of diatoms belonging to 13 families of diatoms. Navicula and Cymbella resulted in the most abundant genera in the two studied stations during February, June, and August over two years $(2017,2018)$. The diatom community is structured, with a diversity index $(\mathrm{H})$ equal to $\sim 2.30$.
\end{abstract}

KEY WORDS Algae; PNEK; polluosensitive; Bacillariophyta; Ramsar.

Received 16.01.2020; accepted 10.05.2020; published online 30.06.2020

\section{INTRODUCTION}

Aquatic ecosystems are subject to multiple pressures from both natural and anthropogenic sources. Factors such as drought, water transfers, eutrophication and the increase in the amount of organic matter due to agricultural and livestock pressures, generate a worsening of the ecological status that affects the communities of organisms associated with these ecosystems.

Diatoms (Bacillariophyta) are organisms distributed in a wide variety of environments around the world, both in aquatic (freshwater and marine) and terrestrial ecosystems. They constitute an enormously diversified group, with ca. 200,000 different species worldwide. Despite their ecological importance and great diversification in the world's aquatic ecosystems, the diatoms of many regions of the world remain virtually unknown. In Algeria, Baudrimont (1974) made a first review of the diatoms historically recorded, confirming that the first systematic algal studies of the region date back to the 1930s. Excluding fossil forms, a total of 400 species of continental diatoms have now been recorded in Algeria, with notable contributions by the eminent archaeologists (Belloc, 1893; Debray, 1897). As for the studies of fossil diatoms, the work of (El Ouahabi et al., 2008) on the diatomites of the Boudinar basin is a primary source. The applicability of biological methods for monitoring water status using diatoms has been successfully tested in several hydrographic basins (Fawzi et al., 2001; Nehar et al., 2015). As a whole, the diatom flora of the region is characterized by the predominance of cosmopolitan elements, with planktonic and benthic communities strongly influenced by nutrient concentrations 
and, above all, by the presence of electrolytes, with clear environmental gradients associated with the presence of different types of cations.

The objective of this work is to perform preliminary characterization of the diatom flora identity at one of the most important lakes at the national and international level, which is the RAMSAR site Oubeïra Lake in northeastern Algeria.

\section{MATERIAL AND METHODS}

\section{Study area}

Oubeïra Lake is located in northeastern Algeria $\left(36^{\circ} 50^{\prime} \mathrm{N}, 8^{\circ} 23^{\prime} \mathrm{E}\right)$; it is part of the El-Kala National Park (NPEK). Oubeïra Lake has been classified as a RAMSAR site since 4 November 1983. It is a naturally occurring, permanent freshwater body with an area of 2257 ha and a depth of $4 \mathrm{~m}$ (Slimani, 2009). Rich in fish (carp); it is a reception area for various species of piscivorous birds such as gulls, seagulls, cormorants or ospreys (Chalabi et al., 1985). The catchment area covers an area of 9900 ha. Oubeïra Lake is a freshwater lake with no flow towards the sea. The Demnet Erihane wadi to the north, the Boumerchène wadi to the northeast, the Wadi Day Graa to the east and the Wadi Messida to the south are the main wadis that feed the lake. During the rains, the waters of Oued El Kebir pass through Oued Messida to reach Oubeïra Lake and are fed by the Monts de la Chèffia (Marre, 1992). When Wadi el Kebir is at its lowest level, in summer, the waters flow in opposite directions (Joleaud, 1936). These waters are found in the sea near Wadi Mafragh. This simplified schema obviously can not reflect the complexity of existing hydrological exchanges (Messerer, 1999).

\section{Physicochemical parameters}

The physicochemical analysis of water in

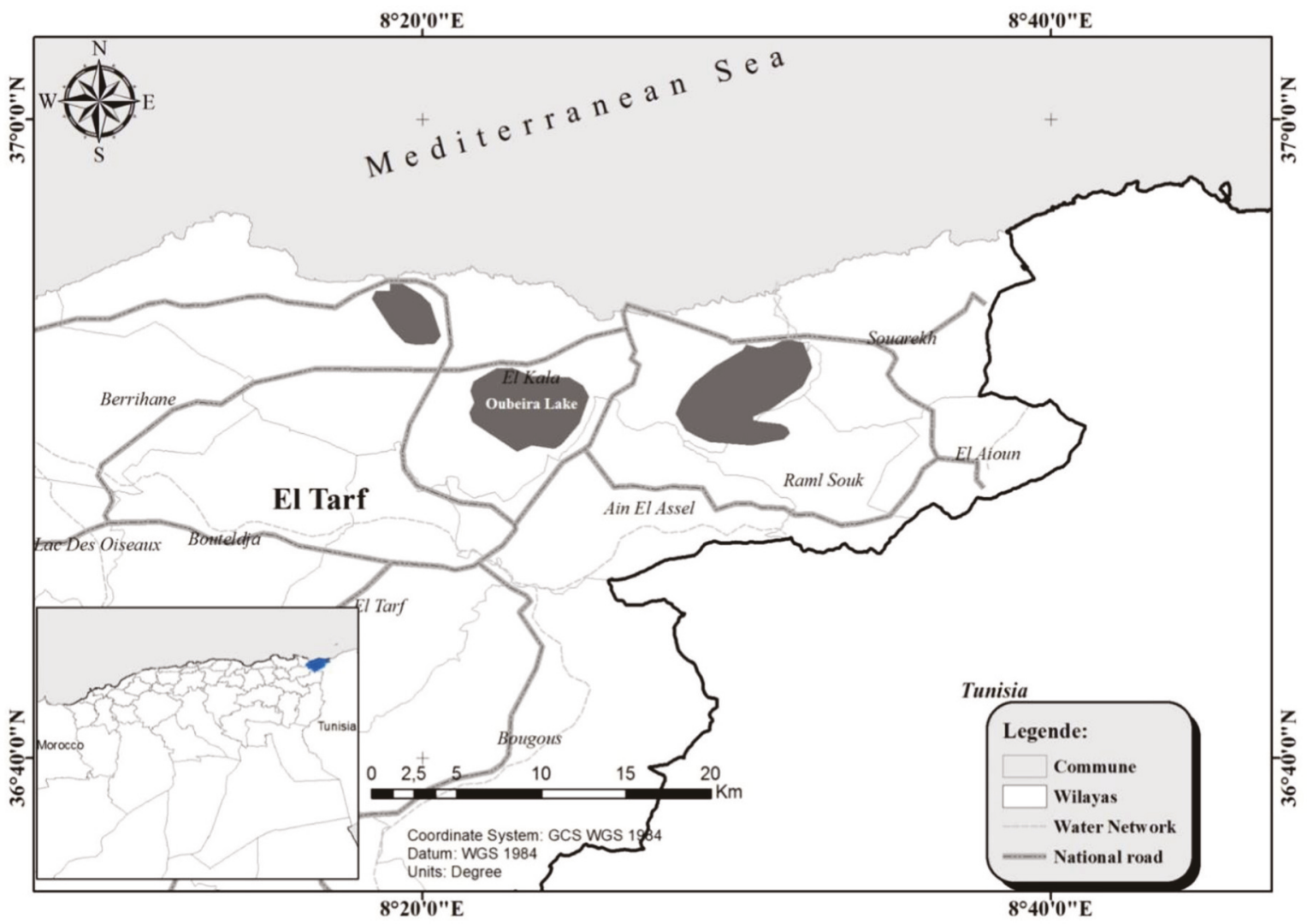

Figure 1. Location of Oubeïra Lake, El Tarf, Algeria (ArcGIS, 2018, modified by Chabaca Hasna). 
Oubeïra Lake is carried out in the field with a multiparameter ( $\mathrm{pH}$, temperature, conductivity). We called on a private water analysis laboratory for the other physicochemical parameters

\section{Collection and preparation of diatoms}

We sampled natural substrates at the edge of the lake collecting biofilm by employing toothbrushes. The collected samples were placed in glass bottles filled with water from the sampling sites, adding neutralized formalin to $10 \%$. In the laboratory, samples were treated with boiling hydrogen peroxide (30\%) for 90 minutes to degrade the organic matter, and for five additional minutes with boiling hydrochloric acid (35\%) to remove the carbonate inclusions. Then, the samples were subjected to a series of centrifugations for five minutes at 2500 rpm and a succession of rinses with distilled water (3 times). An aliquot of the cleaned sample was deposited on a coverslip, dehydrated on a hot plate and mounted with Naphrax resin on a slide (Unité de recherche REBX, 2013 adapted).

\section{Diatom identification}

We performed a microscopic examination of the permanent slides obtained using a LEICA DM
5000 optical microscope. Subsequently, we identified and counted taxa through an immersion oil lens $(1000 x)$. In total, on each slide, we identified at least 400 valves based on previous works by (Noël, 1982; Krammer \& Lange-Bertalot, 1988, 1991a; Rumeau \& Coste, 1988; Meddour, 1988, 1999; Hartley et al., 1996; Al-Asadi et al., 2006; Taylor et al., 2007; Lange-Bertalot et al., 2009; Bey \& Ector, 2013; El Haouati, 2015; Taylor \& Cocquyt, 2016).

\section{RESULTS}

\section{Physicochemical parameters}

The physicochemical parameters of Oubeïra Lake (Table 1) vary according to the season. The average temperature of the water is $21.5^{\circ} \mathrm{C}$, with a maximum value of $30{ }^{\circ} \mathrm{C}$ during the summer period (June, July, and August) and a minimum value of $15^{\circ} \mathrm{C}$ during the winter period (January).

\section{The diversity of benthic diatoms of Oubeïra Lake}

According to our observations, the community identified at Oubeïra Lake is typical of fresh and

\begin{tabular}{|c|c|c|c|c|c|c|c|c|c|c|c|c|}
\hline Year & \multicolumn{6}{|c|}{2017} & \multicolumn{6}{|c|}{2018} \\
\hline Month & \multicolumn{2}{|c|}{ Feb } & \multicolumn{2}{|c|}{ Jun } & \multicolumn{2}{|c|}{ Aug } & \multicolumn{2}{|c|}{ Feb } & \multicolumn{2}{|l|}{ Jun } & \multicolumn{2}{|c|}{ Aug } \\
\hline Station & $\mathrm{S} 1$ & S2 & S1 & S2 & S1 & $\mathrm{S} 2$ & $\mathrm{~S} 1$ & S2 & S1 & S2 & S1 & S2 \\
\hline $\mathrm{T}^{\circ} \mathrm{C}$ & 16 & 16 & 30 & 30 & 30 & 30 & 16 & 16 & 30 & 30 & 30 & 30 \\
\hline $\mathrm{DO}$ & 12 & 12 & 7 & 7 & 5 & 5 & 12 & 12 & 7 & 7 & 5 & 5 \\
\hline $\mathrm{pH}$ & 7 & 7 & 8 & 8 & 8 & 8 & 7 & 7 & 8 & 8 & 8 & 8 \\
\hline Orthophosphates & 2 & 2 & 4 & 4 & 10 & 10 & 2 & 2 & 4 & 4 & 10 & 10 \\
\hline Nitrates & 30 & 30 & 0 & 0 & 30 & 30 & 30 & 30 & 0 & 0 & 30 & 30 \\
\hline Nitrites & 2 & 2 & 1.9 & 1.9 & 3 & 3 & 2 & 2 & 1.9 & 1.9 & 3 & 3 \\
\hline SM & 10 & 10 & 53 & 53 & 42 & 42 & 10 & 10 & 53 & 53 & 42 & 42 \\
\hline
\end{tabular}

Table 1. Physicochemical parameters of Oubeïra Lake during 2017, 2018. 


\begin{tabular}{|c|c|c|c|c|c|c|c|c|c|c|c|c|}
\hline Year & \multicolumn{6}{|l|}{2017} & \multicolumn{6}{|l|}{2018} \\
\hline Month & \multicolumn{2}{|l|}{ Feb } & \multicolumn{2}{|l|}{ Jun } & \multicolumn{2}{|l|}{ Aug } & \multicolumn{2}{|l|}{ Feb } & \multicolumn{2}{|l|}{ Jun } & \multicolumn{2}{|l|}{ Aug } \\
\hline Station & S1 & S2 & S1 & S2 & S1 & S2 & S1 & S2 & S1 & S2 & S1 & S2 \\
\hline S & 17 & 16 & 13 & 15 & 16 & 16 & 14 & 15 & 14 & 14 & 17 & 17 \\
\hline Diversity & 2.331 & 2.323 & 2.33 & 2.277 & 2.41 & 2.434 & 2.133 & 2.211 & 2.213 & 2.223 & 2.311 & 2.255 \\
\hline
\end{tabular}

Table 2. Shannon-weaver $(\mathrm{H})$ diversity index and equitability of Oubeïra Lake.

\begin{tabular}{|c|c|c|c|c|c|c|c|c|c|c|c|}
\hline \multirow{3}{*}{\begin{tabular}{|l|} 
Year \\
Month \\
Station
\end{tabular}} & \multicolumn{6}{|l|}{2017} & \multicolumn{5}{|l|}{2018} \\
\hline & \multicolumn{2}{|l|}{ Feb } & \multicolumn{2}{|l|}{ Jun } & \multicolumn{2}{|l|}{ Aug } & \multicolumn{2}{|l|}{ Feb } & \multicolumn{2}{|l|}{ Jun } & \multirow{2}{*}{$\begin{array}{l}\text { Aug } \\
\text { Sl }\end{array}$} \\
\hline & Sl & S2 & Sl & S2 & Sl & S2 & $\mathrm{Sl}$ & S2 & S1 & S2 & \\
\hline Amphora & 3.96 & 2.237136465 & 5.620608899 & 3.303964758 & 3.95480226 & 3.166226913 & 3.872437358 & 2.202643172 & 5.970149254 & 4.275534442 & 4.022988506 \\
\hline Brachysira & 3.68 & 2.013422819 & 4.683840749 & 2.202643172 & 2.824858757 & 3.957783641 & 2.733485194 & 3.303964758 & 3.731343284 & 2.375296912 & 3.735632184 \\
\hline Caloneis & 7.08 & 6.711409396 & 5.854800937 & 7.709251101 & 5.649717514 & 8.179419525 & 4.555808656 & 7.04845815 & 7.462686567 & 8.313539192 & 6.896551724 \\
\hline Ctenophora & 0.283286119 & 0 & 1.170960187 & 0.8810572687 & 0 & 0 & 0 & 0 & 1.243781095 & 0.9501187648 & 0 \\
\hline Cymbella & 25.49575071 & 26.84563758 & 18.735363 & 22.02643172 & 18.36158192 & 10.55408971 & 29.61275626 & 27.53303965 & 14.92537313 & \begin{tabular}{|l|l|}
18.76484561 \\
\end{tabular} & 20.11494253 \\
\hline Cyclotella & 9.915014164 & 7.158836689 & 11.70960187 & 14.0969163 & 8.474576271 & 10.55408971 & 9.111617312 & 8.810572687 & 11.19402985 & 16.62707838 & 12.93103448 \\
\hline Diatoma & 0.566572238 & 0.4474272931 & 0 & 0 & 1.412429379 & 0.7915567282 & 0.4555808656 & 0.4405286344 & 0.2487562189 & 0.2375296912 & 1.149425287 \\
\hline Diploneis & 0.566572238 & 0.2237136465 & 0 & 0 & 0.5649717514 & 0.5277044855 & 0 & 0 & 0 & 0 & 0.8620689655 \\
\hline Fragilaria & 4.249291785 & 3.803131991 & 5.386416862 & 4.405286344 & 5.649717514 & 5.013192612 & 4.555808656 & 4.845814978 & 6.218905473 & 6.413301663 & 4.310344828 \\
\hline Gomphonema & 0.8498583569 & 2.237136465 & 0 & 0.2202643172 & 1.412429379 & 2.638522427 & 0.6833712984 & 1.101321586 & 0 & 0 & 0.5747126437 \\
\hline Gyrosigma & 11.33144476 & 7.606263982 & 9.601873536 & 8.810572687 & 9.88700565 & 10.55408971 & 13.66742597 & 9.691629956 & 9.950248756 & 9.501187648 & 8.620689655 \\
\hline Melosira & 2.83286119 & 3.803131991 & 4.918032787 & 3.303964758 & 4.237288136 & 5.277044855 & 1.59453303 & 0.8810572687 & 0 & 0 & 1.149425287 \\
\hline Navicula & 14.16430595 & 15.21252796 & 18.735363 & \begin{tabular}{|l|}
16.51982379 \\
\end{tabular} & 19.7740113 & \begin{tabular}{|l|}
19.78891821 \\
\end{tabular} & \begin{tabular}{|l|}
15.9453303 \\
\end{tabular} & 16.96035242 & 27.36318408 & 17.33966746 & 20.11494253 \\
\hline Neidium & 0 & 0 & 0 & 0 & 0 & 0 & 0 & 0 & 0.7462686567 & 0.4750593824 & 0.2873563218 \\
\hline Nitzschia & 8.498583569 & 11.63310962 & 8.196721311 & 11.01321586 & 9.88700565 & 13.19261214 & 10.02277904 & 11.01321586 & 7.213930348 & 10.6888361 & 10.05747126 \\
\hline Pinnularia & 1.699716714 & 3.355704698 & 1.8735363 & 2.202643172 & 2.824858757 & 2.110817942 & 0 & 2.202643172 & 1.243781095 & 1.187648456 & 2.011494253 \\
\hline Surirella & 0.566572238 & 1.565995526 & 0 & 0.6607929515 & \begin{tabular}{|l|}
0.8474576271 \\
\end{tabular} & 1.055408971 & 0.9111617312 & 0.4405286344 & 0 & 0 & 0.2873563218 \\
\hline Synedra & 4.249291785 & 5.14541387 & 3.512880562 & 2.643171806 & 4.237288136 & 2.638522427 & 2.277904328 & 3.524229075 & 2.487562189 & \begin{tabular}{|l|}
2.850356295 \\
\end{tabular} & 2.873563218 \\
\hline
\end{tabular}

Table 3. Average frequency of diatoms identified in two stations at Oubeïra Lake during 2017-2018.

brackish waters. We identified 18 genera belonging to 13 families of diatoms, two genera belonging to the centric morphology (Cyclotella and Melosira) and 16 genera are pennate. This form dominated both two stations of Oubeïra Lake. During the years 2017 and 2018, the genera Cymbella and Navicula dominatedthe two stations of Oubeïra Lake. Caloneis, Cyclotella, Gyrosigma, and Nitzschia are present with average rates, the genera least present in all the stations are: Ctenophora, Diatoma, Diploneis, and Neidium.

The Shannon index calculated according to di- atom surveys (Tables 2, 3) shows that in the year 2017, February S1 and August S1, S2, are the most diverse in diatoms $(17,16,16$ genera of diatoms respectively), by contrast in 2018 , the richest month in diatoms with 17 genera is August (S1 and S2).

\section{DISCUSSION AND CONCLUSIONS}

Our study was conducted at Oubeïra Lake, the physicochemical characteristics change according to the sampling station and period, the water tem- 
perature of the lake varies from $15^{\circ} \mathrm{C}$ in winter to $30^{\circ} \mathrm{C}$ in summer. The results are similar to the works (Bensafia, 2005; Amri, 2008; Sehili, 2008; Djabourabi, 2014) that have been carried out at the Oubeïra Lake, as these seasonal variations allow a good oxygenation of the lake water (Aquaportal, 2016). The average value of the hydrogen potential is slightly alkaline (8.1). This alkalinity could be due to the increase of the diatom communities as reported (Seyni, 2006) and by an increase of oxygen in the water and by $\mathrm{CO} 2$ consume through photosynthesis (Stum \& Morgan, 1991; Martin, 2004). Nutrients are important to the development of photosynthetic microorganisms including diatoms, the orthophosphate reaches a maximum concentration in summer (August) with $10 \mu \mathrm{mol} / 1$. This value would come from the fine sediments which act as accumulator of this element under the usual oxidiz-

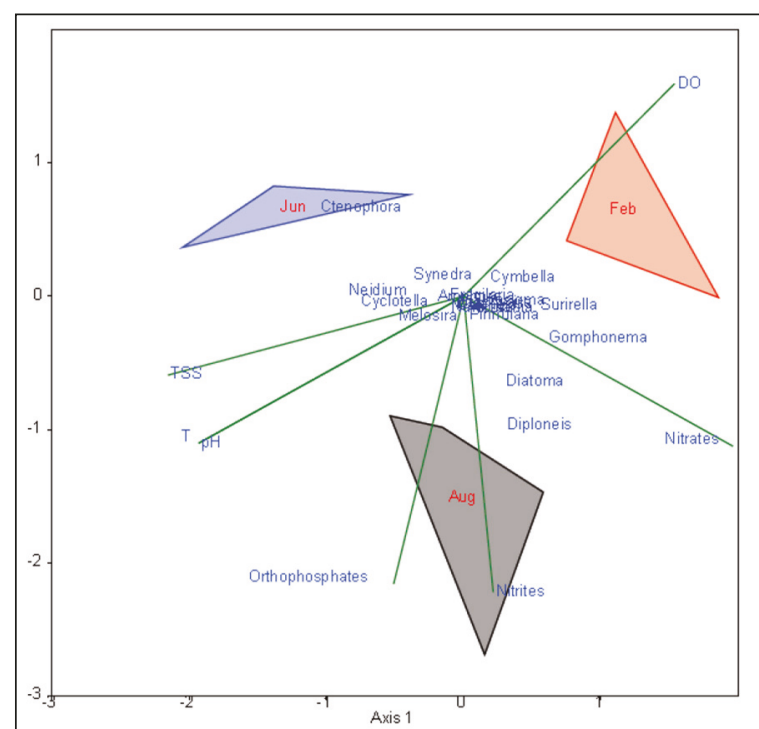

(1)

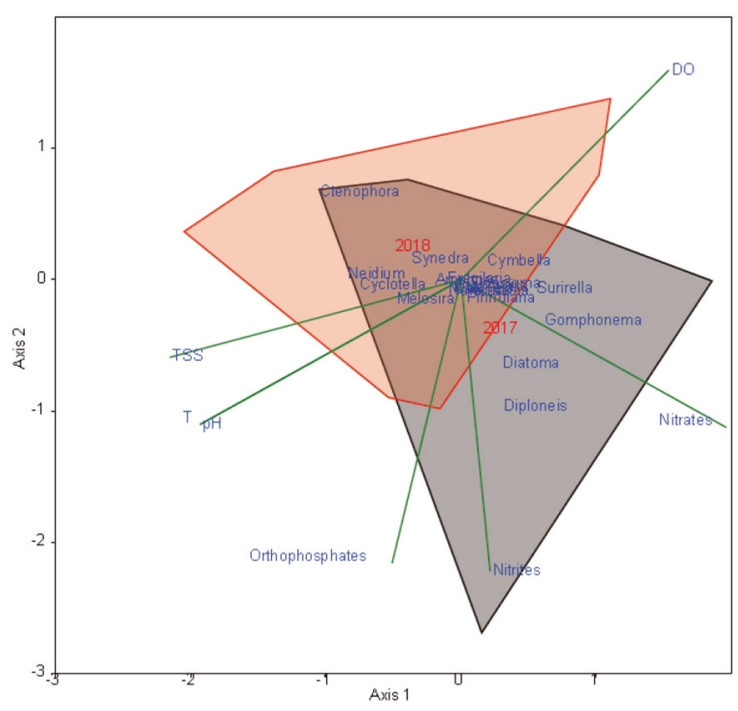

(2)

(3)

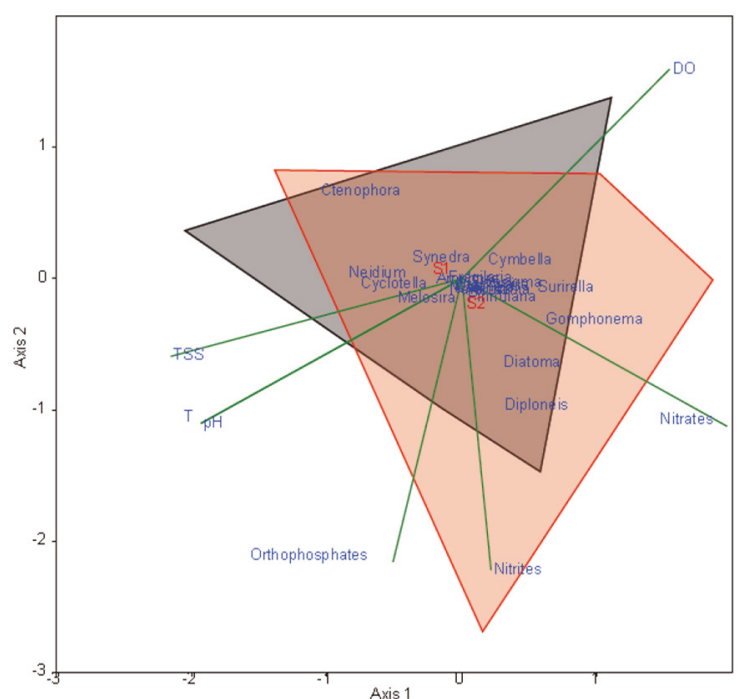

Figure 2. Canonical Correspondence Analysis (CCA) based on correlation between diatoms density and the environmental parameters from Oubeïra Lake at two stations (S1 and S2), during February (Feb), June (Jun) and August (Aug), over two years (2017 and 2018). (1) Canonical Correspondence Analysis (CCA) based on the correlation between months of sampling, diatoms and physicochemical parameters of Oubeïra Lake. (2) Canonical Correspondence Analysis (CCA) based on the correlation between years, diatoms and physicochemical parameters of Oubeïra Lake. (3) Canonical Correspondence Analysis (CCA) based on the correlation between sampled stations (S1 and S2), diatoms and physicochemical parameters of Oubeïra Lake. 
ing conditions to release it in large quantities if the medium becomes reducing (Sehili, 2008). We found low levels of orthophosphate $(0-4 \mu \mathrm{mol} 1)$, these low levels are due to the high phytoplankton biomass consumption of this element (Seyni, 2006). The same author has shown that phosphorus is used to describe the degree of fertility of lakes when the concentration is lower. At $0.32 \mu \mathrm{mol} / 1$ the lake is oligotrophic, while it is between 0.32 and 0.68 $\mu \mathrm{mol} / \mathrm{l}$ in mesotrophic lakes and greater than 0.97 $\mu \mathrm{mol} / 1$ in eutrophic lakes. From these results, Oubeïra Lake is considered oligotrophic in winter and eutrophic in summer. According to our experimental study at Oubeïra Lake, nitrate concentration is very high during the two months of July and January, respectively 40 and $45 \mu \mathrm{mol} / \mathrm{l}$. The elevation of nitrate at the lake level is caused by agricultural discharges. Thus, the concentration of nitrite reaches $6 \mu \mathrm{mol} / 1$ during July. Our results are very similar to those of Sehili in 2008 in the same study area. The suspended matter at the lake level is very high in spring (March) and summer (July). Our results are very similar to those of Dakki (2003) and Sehili (2008), who explained that the abundant precipitation during the winter and the shallow depth of the lake are at the origin of this rise; abundant rainfall generates floods that contribute to the "fattening" of the lakes by allochthonous inputs. The shallow lake facilitates the transfer of sedimentary particles to the water column by waves created by the wind. As for the summer increase of SS in the lake, it may be related to the high microalgal density observed during this period. We can classify Oubeïra Lake as meso-eutrophic in winter (SM in February $=10 \mathrm{mg} / \mathrm{l})$ and hyper-eutrophic $(<25 \mathrm{mg} / \mathrm{l})$ in summer. When environmental conditions are favorable, the development of diatoms is at best.

Microscopic observation of the frustules of diatoms sampled at Oubeïra Lake, allowed us to identify 18 genera, dominated by Cymbella, and Navicula. Sehili (2008) identified 24 genera dominated by Navicula and Fragilaria. The summer period (August) is the most diverse at Oubeïra Lake; this important diatom population is related to the availability of nutrients, light and especially the high concentration of nitrates. At Oubeïra Lake at the two stations, the average values of the indices is equal to $\mathrm{H}(2017)=2.34, \mathrm{H}(2018)=2.22$. Chaïb et al. (2011) and Chaïb \& Tison-Rosebery (2012) reported the dominance of a single species (Achnan- thidium minutissimum) in the wadi el Kebir in northeastern Algeria, the mean values of the Shannon index is equal to $\mathrm{H}=3.7$. In northwestern Algeria, Nehar et al. (2015) studied the diatoms of Oued El Hammam and calculated this index as $\mathrm{H}=1.9$.

In conclusion, Oubeïra Lake is considered meso-eutrophic in winter and hyper-eutrophic in summer, due to its proximity to neighboring farmland using uncontrolled releases of fertilizers. The availability of nutrients at Oubeïra Lake and the surrounding favorable conditions have contributed positively to the richness of the diatom community. The Oubeïra Lake is a protected natural reserve which shelters a very diversified fauna and flora, the alarming state of this lake is due to the traditional agriculture with its irrational use of the fertilizer and thus the intensive irrigation participant to its degradation and lead it towards eutrophication. Permanent monitoring of the water quality of Oubeïra Lake is required, and diatoms can be used as bioindicators of water quality.

\section{REFERENCES}

AquaPortail. 2016. Lac Eutrophe: Définition Et Explications. [online] Available at: https://www.aquaportail. com/definition-13107-lac-eutrophe.html [Accessed 16 June 2016].

Al-Asadi M.S. \& Randerson P. \& Benson-Evans K., 2006. Phytoplankton population dynamics in three west Algerian rivers: I. The river Cheliff and its tributary, the river Mina. Marina Mesopotamica Online, 1: $48-72$.

Amri S., 2008. Dynamique mensuelle du phytoplancton dans le lac Oubeira et le lac Noir "Parc National ELKala", thèse de magistère, Université Badji MokhtarAnnaba, 94 pp.

Baudrimont R., 1974. Recherches sur les Diatomées des eaux continentales de l'Algérie: écologie et paléoécologie. Mémoires de la Société d'histoire naturelle de l'Afrique du Nord, 12: 1-249. http://catalogue.bnf.fr/ark:/12148/cb359144466

Belloc E., 1893. Algues microscopiques des eaux thermales et salées d'Algérie et de Tunisie, suivies d'Uune liste des diatomées fossiles et d'un aperçu de la forule diatomioue marine littorale. Revue biologique du nord de la France, 5: 209-236.

Bensafia N., 2005. Les peuplements de cyanobactéries de deux plans d'eau (Lac Oubéira, Lac Tonga): inventaire et dynamique spatiotemporelle. Mémoire 2005. Diplôme de Magister en Sciences de la Mer. Université d'Annaba, Algeria. 
Bey M.Y. \& Ector L., 2013. Atlas des diatomees des cours d'eau de la region Rhône-Alpes. (1). Centriques, Monoraphidees. (2). Araphidees, Brachyraphidees. (3). Naviculacees: Naviculoidees. (4). Naviculacees: Naviculoidees. (5). Naviculacees: Cymbelloidees, Gomphonematoidees. (6). Bacillariacees, Rhopalodiacees, Surirellacees. Direction regionale de l'Environnement, de l'Amenagement et du Logement Rhône-Alpes, Lyon, 1182 pp.

Chaïb N., Alfarhan A.H., Al-Rasheid K.A.S. \& Samraoui B., 2011. Environmental determinants of diatom assemblages along a North African wadi, the KebirEast, Northeast Algeria. Journal of Limnology, 70: 33-40 https://doi.org/10.4081/jlimnol.2011.33

Chaïb N. \& Tison-Rosebery J., 2012. Water quality assessment and application of the biological diatom index in the Kebir-East wadi, Algeria. African Journal of Aquatic Science, 37: 59-69 https://doi.org/ $10.2989 / 16085914.2011 .636898$

Chalabi B., Skinner J., Harrison, J. \& Van Dijk., 1985. Les zones humides du nord-est Algérien en 1984. Observation ornithologiques. Report $\mathrm{N}^{\circ} 8$. Stiching Wiwo, Nederland, 45pp

Dakki M., 2003. Rapport: diagnostic pour l'aménagement des zones humides du nord-est du Maroc: 2. Sebkha Bou Areg (lagune de Nador) Institut Scientifique, Rabat

Debray F., 1897. Catalogue des algues du Maroc, d'Algerie et de la Tunisie. A. Jourdan, Alger, 78 pp.

Djabourabi A., 2014. Impact de facteurs environnementaux et de microalgues toxiques sur certains organismes aquatiques (bivalves). These de doctorat: Sciences de la Mer. Université Badji Mokhtar, Annaba, 210 pp.

El Haouati H., 2015. Study of the diatoms of reghaia lake, northern Algeria. Revue d'Ecologie (Terre et Vie), 70: 44-57.

El Ouahabi F.Z.E., Saint Martin S., Saint Martin J.P., Moussa A.B. \& Conesa G., 2008. Les assemblages de diatomées du bassin messinien de Boudinar (Maroc nord-oriental). Revue de Micropaléontologie, 50: 149-167. https://doi.org/10.1016/j.revmic. 2007.02.004

Fawzi B., Chlaida M., Oubraim S., Loudiki M., Sabour B. \& Bouzidi A., 2001. "Application de certains indices diatomioues à un cours d'eau marocain: Oued Hassar". Journal Water Science, 14: 73-89. https:// doi.org/10.7202/705410

Hartley B., Barber H.G., Carter J.R. \& Sims P.A., 1996. An Atlas of British diatoms (Book, 1996) Bristol, England: Biopress, England, 601 pp.

Joleaud L., 1936. Etude géologique de la région de Bône et de la Calle. Mémoires et Bulletins du Service de la Carte Géologique de l'Algérie, Imp. Typo-Litho et Cie, Alger, 2ème série, stat, $\mathrm{N}^{\circ} 12,185$ pp.
Krammer K. \& Lange-Bertalot H., 1988. Bacillariophyceae, (2), Epithemiaceae, Bacillariaceae, Surirellaceae. Band 2/2: Süßwasserflora von Mitteleuropa (begründet von A. Pascher) - Gustav Fischer, Stuttgart, $576 \mathrm{pp}$.

Krammer K. \& Lange-Bertalot H., 1991. Bacillariophyceae, (3), Centrales, Fragilariaceae, Eunotiaceae. Band 2/3: Süßwasserflora von Mitteleuropa (begründet von A. Pascher) - Gustav Fischer, Stuttgart, 576 pp.

Lange-Bertalot H., Fumanti B., Cavacini P. \& Tagliaventi N., 2009. The genus Navigiolum (Bacillariophyceae) in Mediterranean and North African rock pool habitats: description of four new species from Algeria. Fottea, 9: 179-185. https://10.5507/fot. 2009.018

Marre A., 1992. Le Tell Oriental Algérien, de Collo à la frontière tunisienne: étude géomorphologique. Office des Pubblications universitaires, Vol. 2. Alger, 624 pp.

Meddour A., 1988. Parasites of Freshwater Fishes from Lake Oubeira, Algeria. Thesis of Master of Science, Department of Zoology, the University of Liverpool, U.K., 146 pp.

Meddour A., 1999. Parasites affectant l'ichtyofaune du Lac Oubeira, El Kala. (Communication) 4èmes Journée Nationales de Parasitologie, Annaba, Société Algérienne de Parasitologie, Institut Pasteur Alger, 9 pp. (Unpublished data).

Martin B.V., 2004. Floraisons de cyanobactéries au lac saint-augustin: dynamique à court terme et stratification, Thèse Université Laval, 45 pp.

Messerer Y., 1999. Etude morpho-métrique et hydrographique du complexe lacustre d'El-Kala; cas du lac Oubeira et du lac mellah. Thèse de magister, Université Annaba, 123 pp.

Nehar B., Blanco B. \& Hadjadj Aoul S., 2015. Diversity and ecology of diatoms in northwest of Algeria: case of El-Hammam stream and estuary of Chelif river. Applied Ecology and Environmental Research, 13: 37-52. https://doi.org/10.15666/aeer/ 1301037052

Noël D., 1982. Les Diatomées des saumures des marais salants de Salin-de-Giraud (Sud de la France). Géologie Méditerranéenne, 9: 413-446. https://doi.org/10. 3406/geolm.1982.1218

Rumeau A. \& Coste M., 1988. Initiation à la systématique des diatomées d'eau douce Pour l'utilisation pratique d'un indice diatomique générique. Bulletin Français de la Pêche et de la Pisciculture, 309: 169. https://doi.org/10.1051/kmae:1988009

Sehili N., 2008. Evolution des peuplements phytoplanctoniques au niveau du lac Oubeïra et la lagune El Mellah. Thèse de Magistère, Université Badji Mokhtar-Annaba, 135 pp. 
Slimani A., 2009. Evaluation et valorisation des potentialités phylogénétiques fourragères sur les berges des lacs Tonga, Oubeira et le lac des oiseaux dans la région d'El Tarf. Thèse de doctorat, Université Annaba, $162 \mathrm{pp}$.

Seyni S., 2006. Contrôle environnemental de la production primaire du lac de Guiers au Nord du Sénégal Thèse de Doctorat de 3ème cycle de Biologie Végétale. Université Cheikh Anta Diop de Dakar.

Stum W. \& Morgan J.J., 1991. Aquatique chemistry. An introduction emphasizing chemical equilibria in natural waters 2 eme Ed., J.Wiley \& Sons, 790 pp.

Taylor J.C., Prygiel J., Vosloo A., De La Rey P.A. \& Van Rensburg L., 2007. Can diatom based pollution indices be used for bio-monitoring in South Africa? A case study of the Crocodile West and Marico water management area. Hydrobiologia, 592: 455-464. https://doi.org/10.1007/s10750-007-0788-1

Taylor J.C. \& Cocquyt C., 2016. Diatoms from the Congo and Zambezi basins. Methodologies and identification of the genera. Abc Taxa, (Congo) volume 16, 364 pp. https://doi.org/10.2989/16085914.2019.

Unité de recherche REBX, I., 2013. Echantillonnage Des Communautés De Phytobenthos En Plans D'Eau. [ebook] Available at: <https://hydrobio-dce.irstea. fr/wp-content/uploads/2014/06/130218_V1_2_ Echantillonnage_PhytoBenthos_PE_Irstea.pdf $>$ [Accessed 5 June 2020]. Rsis.ramsar.org. 2018. Réserve Intégrale Du Lac Tonga | Service D'Information Sur Les Sites Ramsar. [online] Available at: $<$ https://rsis.ramsar.org/fr/ris/281?language $=$ fr $>$ [Accessed 2 June 2016]. 